\title{
Influence of urbanisation on water quality in the basin of the upper Uruguay River in western Santa Catarina, Brazil
}

\author{
Influência da urbanização sobre a qualidade da água na \\ bacia do alto Rio Uruguai no oeste de Santa Catarina, Brasil
}

\section{Raquel Zeni Ternus ${ }^{1}$, Gilza Maria de Souza-Franco ${ }^{2}$, Maria Elena Krombauer Anselmini ${ }^{1}$, Douglas João Carlos Mocellin ${ }^{1}$ and Jacir Dal Magro²}
${ }^{1}$ Programa de Pós-Graduação em Ciências Ambientais, Universidade Comunitária da Região de Chapecó - UNOCHAPECÓ, Chapecó, SC, Brazil e-mail: razet@unochapeco.edu.br, maryelenk@gmail.com,d.jc@unochapeco.edu.br
${ }^{2}$ Área de Ciências Exatas e Ambientais, Programa de Pós-Graduação em Ciências Ambientais, Universidade Comunitária Regional de Chapecó - UNOCHAPECÓ, Chapecó, SC, Brazil e-mail: gfranco@unochapeco.edu.br, jacir@unochapeco.edu.br

\begin{abstract}
Aim: The main objective of the study was to evaluate the limnological characteristics of rivers flowing through urban and rural areas in the upper Uruguay River basin in western Santa Catarina (SC), Brazil. Methods: Sampling sites in the tributaries were selected along the longitudinal gradient and the different use of the soil in adjacent areas. Samples were collected bimonthly from March 2005 to August 2006. The following were analysed: depth, $\mathrm{pH}$, electrical conductivity, dissolved oxygen concentration (DO), water temperature, chemical oxygen demand (COD), total alkalinity, ammonia, nitrite, nitrate and phosphorus were analysed. Results: In most of the rivers analysed, we found a continuum from the spring to the river mouth that was characterised by a gradual increase in electrical conductivity, COD, phosphorus, alkalinity, nitrite and nitrate. However, an alteration from this pattern was found in rivers passing through urban areas. This deviation was due to high organic matter input poured into the rivers from these areas. Conclusions: Degraded riparian forest was observed along most of the bodies of water, which facilitates the entry of pollutants. Although the studied area suffers from intense farming activity (agriculture and livestock) and has the highest concentration of swine livestock in the country, the rivers that were most altered from their natural state were those that were influenced by sewage and industrial effluents from urban development.
\end{abstract}

keywords: fluvial limnology, pollution, phosphorus.

Resumo: Objetivo: O objetivo desta pesquisa foi avaliar as características limnológicas de rios que atravessam áreas rurais e urbanas na bacia do alto Rio Uruguai no oeste de Santa Catarina, Brasil. Métodos: Foram selecionados pontos nos afluentes, obedecendo ao gradiente longitudinal e diferente uso do solo das áreas adjacentes. As amostragens foram bimestrais de março de 2005 a agosto de 2006. Foram analisadas as variáveis profundidade, $\mathrm{pH}$, condutividade elétrica, oxigênio dissolvido $(\mathrm{OD})$, temperatura da água, demanda química de oxigênio (DQO), alcalinidade total, amônia, nitrito, nitrato e fósforo. Resultados: Os resultados evidenciaram que para a maioria dos rios, da nascente até a foz, há um contínuo, caracterizado pelo aumento gradual da condutividade elétrica, da DQO, fósforo, alcalinidade, nitrito e nitrato. No entanto, para rios que atravessam áreas urbanas, verificou-se desvio desse padrão ocasionado pela elevada entrada de material orgânico. Conclusóes: Foi observado mata ciliar degradada na maioria dos corpos d'água estudados, o que facilita a entrada de poluentes. Embora a região estudada sofra a pressão de uma intensa atividade agrícola (agricultura e pecuária) e com a maior concentraçáo de criação de suínos do país, foi verificado que os rios mais alterados em suas características originais foram aqueles que recebem influência da área urbana com lançamento de esgoto e efluente industrial.

Palavras-chave: limnologia fluvial, poluição, fósforo. 


\section{Introduction}

Environmental impacts have significantly altered aquatic ecosystems such as rivers and streams (Ouyang et al., 2006; Cunha et al., 2010). These ecosystems are highly susceptible to environmental changes because they constitute an open environment where river basins interact with their immediate surroundings. Environmental changes may thus damage the biodiversity and/or the functionality of these ecosystems (Zhang, 2007; Zimmermann et al., 2008).

Timber exploitation was the first economic activity to atract population settlement in the western region of Santa Catarina State (Bellani, 2006; Renk, 2006; Wentz, 2004; Werlang, 2006). In the beginning of the nineteenth century, the region was further occupied when cattle breeding and, later, mate herb harvesting, began to develop. However, an effective occupation of the region only occurred after 1917 with the development of companies commercialising the region's land and wood (Maestri, 2005). Colonisation, together with an intensive exploitation of natural resources, livestock farming, the use of fertilisers and agrochemicals and urbanisation have increased the amount of waste, domestic sewage and industrial effluents found in the aquatic ecosystems of this region (Denardin and Sulzbach, 2005), causing degradation of the water resources (Schuster and Souza-Franco, 2003; Dal Pissol and Souza-Franco, 2003; Bottin et al., 2007; Bonai et al., 2009). Organic pollution is a primary factor associated with the loss of diversity and the loss of ecological balance in an ecosystem (Meirelles-Pereira et al., 2005; Araújo and Tejerina-Garro, 2007; Schulz and Martins-Junior, 2001, McKie et al., 2009). The natural characteristics of the Santa Catarina western region (Schuster and Souza-Franco, 2003; Dal Pissol and Souza-Franco, 2003; Bottin et al., 2007; Bonai et al., 2009) have changed primarily because of pollution and deforestation. Furthermore, in the quest for new economic ventures, artificial reservoirs for electricity generation have been constructed in the upper Uruguay River region and have further degraded the region's water quality.

In this study, we examined the influence of urbanisation and agriculture in western Santa Catarina along tributaries of the Uruguay River. According to the IBGE (2008), Santa Catarina State is the largest swine producer in Brazil, and our studied area is located in the State's main swine producing counties. The danger of pollution from swine manure is well-known (Stone et al.,
1998; Mattias et al., 2010), and it has a high potential to contaminate both shallow and deep water (Stone et al. 1998; Doblinski et al., 2010; Mattias et al., 2010). Moreover, urban growth can significantly degrade surface water (Rahman and Lee, 1997; Karn and Harada, 2001, Ouyang et al., 2006; Goonetilleke et al., 2005; Praus, 2007, Cunha et al., 2010). In Brazil, urban waste is often dumped into natural river systems, which creates unsuitable conditions downstream (Lima and Zakia, 2004). According to IBGE (2002), $10.23 \%$ of the cities in Santa Catarina have sewage treatment systems. However, data from the National Information System on Sanitation report that in 2008 only two counties in the studied area had sewage treatment facilities (SNSA, 2010). Several commonly measured features of water quality, including nitrite, nitrate, and phosphorus, are sensitive to sewage inputs and are recognized indicators of poor water quality.

In our study, we assume that urban areas negatively influence the water quality of nearby aquatic systems, and that riparian vegetation contributes to maintaining the environmental quality of local rivers. The aim of our study was to evaluate the physical and chemical characteristics of water in rivers flowing through urban and rural areas in the upper Uruguay River basin in western Santa Catarina State, Brazil.

\subsection{Material and Methods}

The studied region is located between the Itá and Mondai municipalities (SC) in the upper Uruguay River Basin. Samples were collected from nine rivers that are tributaries of the upper Uruguay River Basin: Irani, Xaxim, Taquaruçu, Lajeado São José, Lambedor, Lajeado Bonito, Palmitos, São Domingos and Iracema (Figure 1). Field observations were conducted to characterise vegetation, land use and the environment. We characterised aquatic habitat diversity and examined the presence of riparian vegetation and its composition (exotic or native vegetation). At each sampling site we assessed riparian vegetation according to Hannaford et al. (1997); a score was assigned to measure the presence and integrity of vegetation: good $=3$ points (areas with more than $90 \%$ of native vegetation), suboptimal $=2$ points (areas with $70-90 \%$ of native vegetation), moderate $=1$ point (areas with $50-70 \%$ of native vegetation), and poor $=$ zero points (areas with $<50 \%$ of native vegetation).

Six samples were collected from each river bimonthly between March 2005 and August 2006 


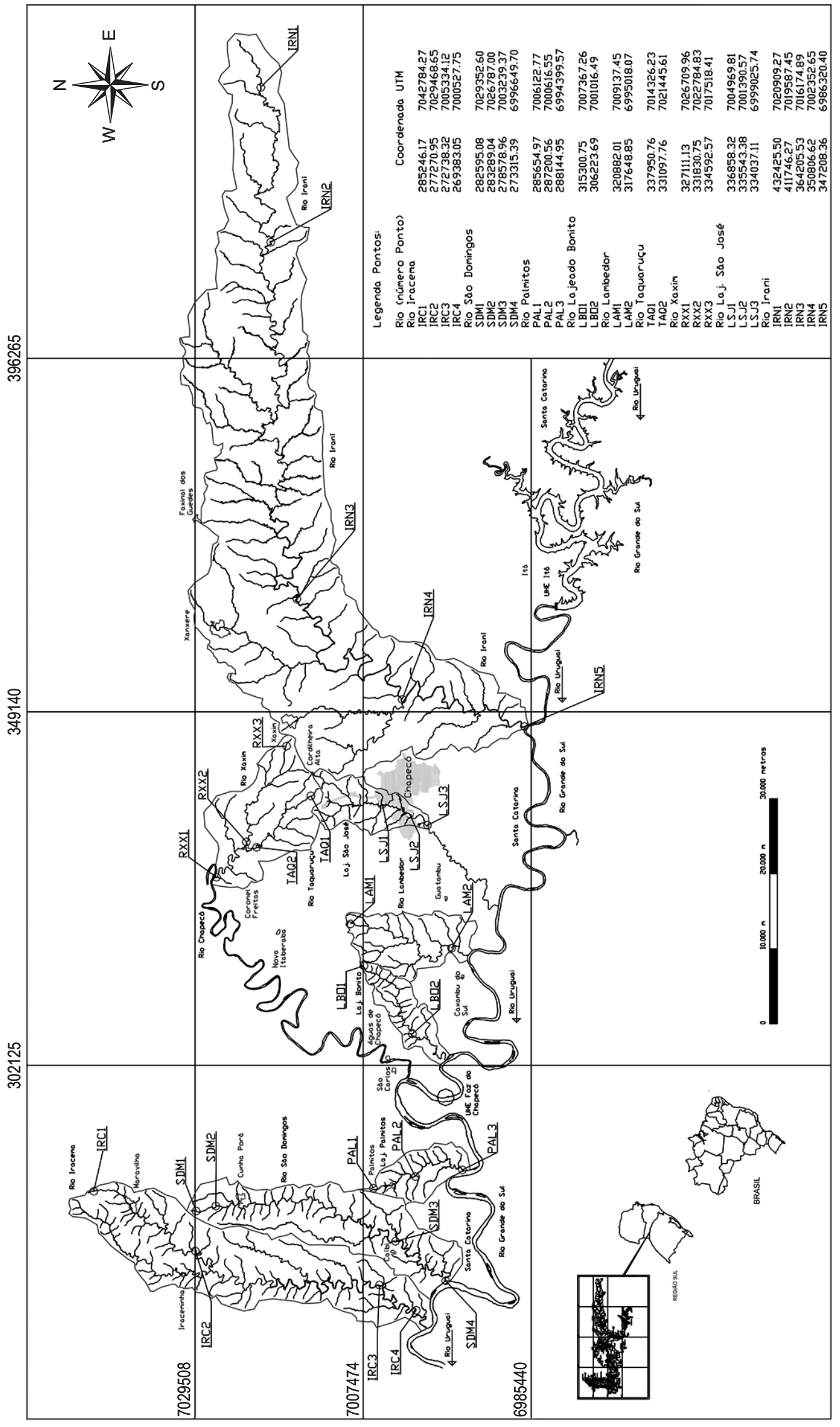


( $\mathrm{N}=6$ for each river). They were collected along the longitudinal gradient from the spring to the river mouth. Water samples were collected on the sub-surface, transferred to polyethylene bottles and kept on ice in Styrofoam boxes until they arrived at the laboratory. At each site and for each sample, we measured sample depth $(\mathrm{m})$, water temperature $\left({ }^{\circ} \mathrm{C}\right), \mathrm{pH}$, and dissolved oxygen content (DO mg. $\mathrm{L}^{-1}$ ). In the laboratory we recorded total alkalinity $\left(\mathrm{mg} \cdot \mathrm{L}^{-1}\right)$, chemical oxygen demand COD (mg. $\left.\mathrm{L}^{-1}\right)$, ammonia nitrogen (mg. $\left.\mathrm{L}^{-1}\right)$, nitrite $\left(\mathrm{mg} . \mathrm{L}^{-1}\right)$, nitrate $\left(\mathrm{mg} . \mathrm{L}^{-1}\right)$ and total phosphorus (mg.L $\mathrm{L}^{-1}$ ) of each sample (APHA, 1998). Electrical conductivity $\left(\mu \mathrm{S} . \mathrm{cm}^{-1}\right)$ was also measured in the laboratory using a Químis digital conductivity meter (model Q405B).

Analysis of the data during the monitoring and the sampling periods was conducted using a principal components analysis (PCA), the Statistica 6.0 program (STATSOFT, 2001). Variables were standardised through logarithmic transformation to make them dimensionless (excluding $\mathrm{pH}$ ). With regard the principal component analysis (PCA), we included urban and rural rivers. We considered "urban rivers" the ones crossing cities and "rural rivers" the ones crossing rural areas. We classified urban river sites as "city" (i.e. inside the city limits), "upstream" and "downstream" (i.e. located outside the city limits and depending on the location with respect to the river stream).

\section{Results}

Of the nine studied rivers, only Lambedor and Lajeado Bonito exclusively cross rural areas. In the case of Irani River, all sampling sites are located in rural areas. This river can be considered almost exclusively rural except only in a small section near the small town of Arvoredo (SC) which was not sampled (Table 1). The other rivers cross cities; Lajeado São José River has most of its stream in the city of Chapecó, which is the largest city in western Santa Catarina. With regards to the integrity of the vegetation, most of the sampling sites were classified with zero or 1 point (according to Hannaford et al., 1997) except in Irani River where in two sampling sites the vegetation was scored with 2 points (Table 1), indicating a good degree of conservation of riparian vegetation.

Table 1. Characterisation of sites and rivers sampled between 2005 and 2006. UZ: Urban Zone; RZ: Rural Zone. *Classification according to Hannaford et al. (1997).

\begin{tabular}{|c|c|c|c|c|}
\hline River & Site & Region & Sediment & Riparian florest* \\
\hline \multirow[t]{4}{*}{ Iracema } & IRC1 & RZ & sand & 0 \\
\hline & IRC2 & UZ & boulder & 1 \\
\hline & IRC3 & RZ & sand & 1 \\
\hline & IRC4 & RZ & sand & 1 \\
\hline \multirow[t]{5}{*}{ Irani } & IRN1 & RZ & boulder & 2 \\
\hline & IRN2 & RZ & boulder and organic material & 1 \\
\hline & IRN3 & RZ & boulder & 1 \\
\hline & IRN4 & RZ & boulder & 2 \\
\hline & IRN5 & RZ & boulder & 2 \\
\hline \multirow[t]{2}{*}{ Lambedor } & LAM1 & RZ & flagstone & 0 \\
\hline & LAM2 & RZ & boulder & 1 \\
\hline \multirow[t]{2}{*}{ Lajeado Bonito } & LBO1 & RZ & organic material & 0 \\
\hline & LBO2 & RZ & boulder & 1 \\
\hline \multirow[t]{4}{*}{ Lajeado São José } & LSJ1 & RZ & flagstone / boulder & 0 \\
\hline & LSJ2 & UZ & mud & 1 \\
\hline & LSJ3 & UZ & boulder & 1 \\
\hline & LSJ4 & RZ & boulder & 0 \\
\hline \multirow[t]{3}{*}{ Palmitos } & PAL1 & RZ & mud & 0 \\
\hline & PAL2 & RZ & boulder & 0 \\
\hline & PAL3 & $\mathrm{RZ}$ & mud & 0 \\
\hline \multirow[t]{3}{*}{ São Domingos } & SDM1 & RZ & mud / organic material & 1 \\
\hline & SDM2 & UZ & boulder & 1 \\
\hline & SDM3 & RZ & sand / boulder & 1 \\
\hline \multirow[t]{2}{*}{ Taquaruçú } & TAQ1 & RZ & mud / boulder & 1 \\
\hline & TAQ2 & UZ & boulder & 0 \\
\hline \multirow[t]{3}{*}{ Xaxim } & XAX1 & RZ & mud / organic material & 0 \\
\hline & XAX2 & UZ & boulder & 0 \\
\hline & XAX1 & RZ & sand & 1 \\
\hline
\end{tabular}


The values of the physical and chemical variables for the sampling sites are summarized in Table 2 . The rivers we analysed were generally shallow, the deepest mean depth was recorded in the São Domingos River and the shallowest mean depth was recorded in the Lambedor River. The mean water temperature was $18.17{ }^{\circ} \mathrm{C}$. The $\mathrm{pH}$ values of the rivers were generally close to neutrality. A trend in electrical conductivity was observed and was related to spatial gradient; the lowest values were recorded in the Irani River, whereas the highest values were obtained in the Lajeado São José River, especially at the mouth (RLSJ4). A similar trend was observed for total alkalinity, the mean values ranged from $16.93 \mathrm{mg} . \mathrm{L}^{-1}$ to $39.53 \mathrm{mg} . \mathrm{L}^{-1}$ in the Irani and Xaxim Rivers, respectively, and the highest spatial range was recorded in the Lajeado São José River. Dissolved oxygen concentrations (DO) varied among rivers and among sites within each river. The highest mean DO values were recorded in the Irani and Palmitos Rivers, whereas the lowest values were recorded in the Lajeado Bonito River, (site RLB1) and Iracema River (site RIC1). COD values' mean was $16.02 \mathrm{mg} . \mathrm{L}^{-1}$, and ranged from $4.05 \mathrm{mg} . \mathrm{L}^{-1}$ in the Lajeado Bonito River to $52.10 \mathrm{mg} . \mathrm{L}^{-1}$ in the São Domingos River.

Ammonia concentrations were highest in the Lajeado São José River, especially in the site RLSJ4.
Nitrite concentrations ranged from $0.005 \mathrm{mg} . \mathrm{L}^{-1}$ to $0.070 \mathrm{mg} . \mathrm{L}^{-1}$ in the Sáo Domingos River and the Taquaruçu River, respectively. High nitrate values were observed in the majority of the samples collected from the Taquaruçu River, while low mean nitrate values were found in samples collected from the Irani River. The highest mean nitrite concentrations were recorded in the Xaxim, Taquaruçu and Lajeado São José Rivers, whereas the highest mean nitrate concentrations were recorded in these rivers as well as in the São Domingos River. The phosphorus concentrations recorded were high for most sampling sites. The highest concentrations were recorded in the Lajeado São José River.

Figure 2 shows the scores and weights associated with urban and rural rivers. The PCA revealed that axes 1 and 2 had values greater than 1 . These axes explained $44.66 \%$ of the sample variability; $29.96 \%$ of sample variability was contributed by component 1 and $14.70 \%$ was contributed by component 2 . The first principal component (PC1) could discriminate between the rural and urban rivers; left of $\mathrm{PC} 1$ are the urban rivers characterised by high electrical conductivity, total alkalinity, ammonia, nitrite and total phosphorus. The second principal component (PC2) described the separation of the rivers as a function of dissolved oxygen concentration, COD and depth.

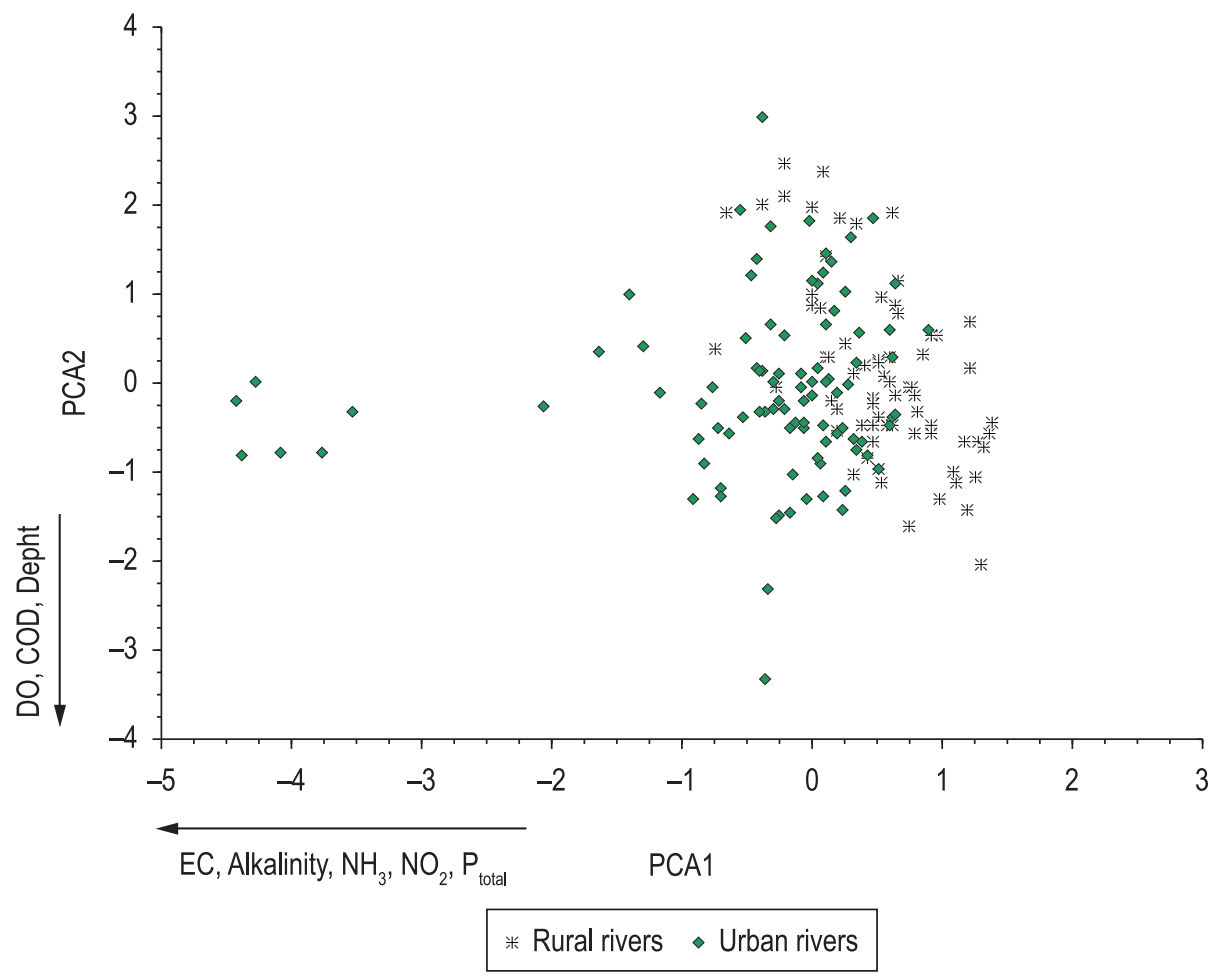

Figure 2. Ordination diagram by Principal Component Analysis (PCA) of scores and weights associated with urban and rural rivers. 


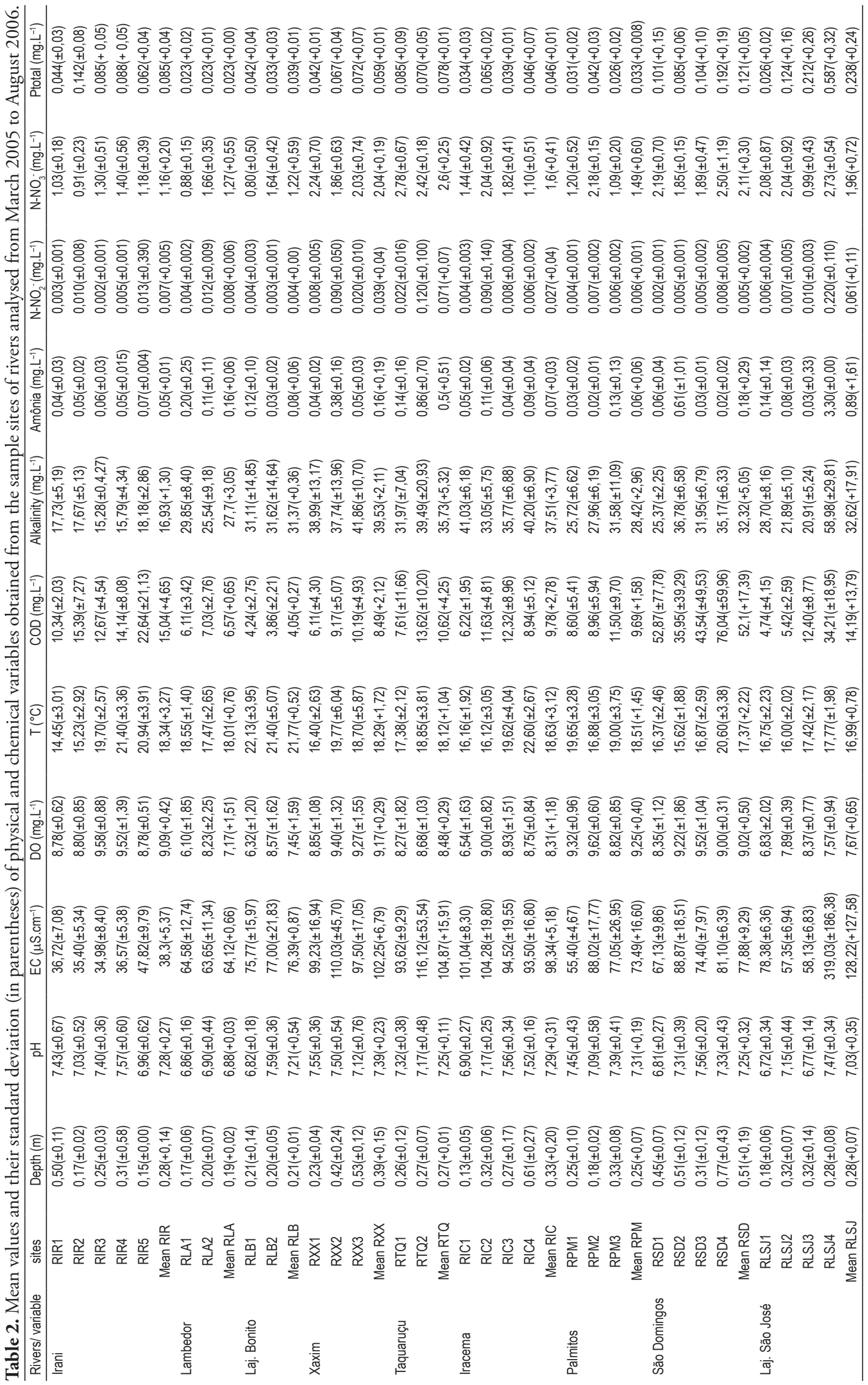


Figure 3 shows the scores and weights assigned to sampling sites in the urban rivers categorised as upstream and downstream of the urban area. The PCA revealed that axes 1 and 2 had values greater than 1 . These axes explained $46.82 \%$ of the sample variability; $31.75 \%$ of sample variability was contributed by component 1 and $15.07 \%$ was contributed by component 2 . PC1 discriminated the sample site RLSJ4, which was located downstream of the Chapeco River and was characterised as having high electrical conductivity, total alkalinity, ammonia, nitrite and total phosphorus. PC2 described the separation of sample sites as a function of $\mathrm{pH}$, dissolved oxygen, COD and depth.

The Figure 3 shows the graphical biplot of scores and weights assigned to sites located in urban rivers, categorized as upstream and downstream of the urban area. The PCA revealed that axes 1 and 2 exhibited values greater than 1 . These axes explained $38.34 \%$ of the sample variability; $24.21 \%$ of sample variability was contributed by component 1 and $14.13 \%$ was contributed by component 2 . PC1 discriminated between the samples from the Irani River, which was characterised by having high levels of dissolved oxygen and low values of conductivity and total alkalinity. PC2 described the separation of samples as a function of $\mathrm{pH}$ and temperature.

\section{Discussion}

In the majority of the rivers we examined (from spring to river mouth), the trend is a gradual increase in electrical conductivity, COD, phosphorus, alkalinity, nitrite and nitrate. However, we noticed an alteration from this pattern in rivers passing through urban areas (e.g., Lajeado São José, São Domingos, Iracema, Taquaruçu and Xaxim); a high input of organic matter from human activities increased the values of these variables. This change has also been documented in other subtropical rivers (Mirande et al., 1999; Salomoni et al., 2007).

The entry of organic matter and nutrients from natural allochthonous and/or anthropogenic sources into aquatic ecosystems may influence the water's $\mathrm{pH}$ values and dissolved oxygen concentrations. However, in this study, despite the existence of input of organic matter and nutrients close to various sampling sites (site RXX2 of the Xaxim River, site RTQ2 of the Taquaruçu River and site RLSJ3 of the Lajeado São José River), we did not notice any changes in the water's $\mathrm{pH}$ values or dissolved organic concentrations at these locations. The stability of the $\mathrm{pH}$ may be associated with the high total alkalinity values recorded in these rivers and, consequently, with a high buffering capacity. With respect to DO,

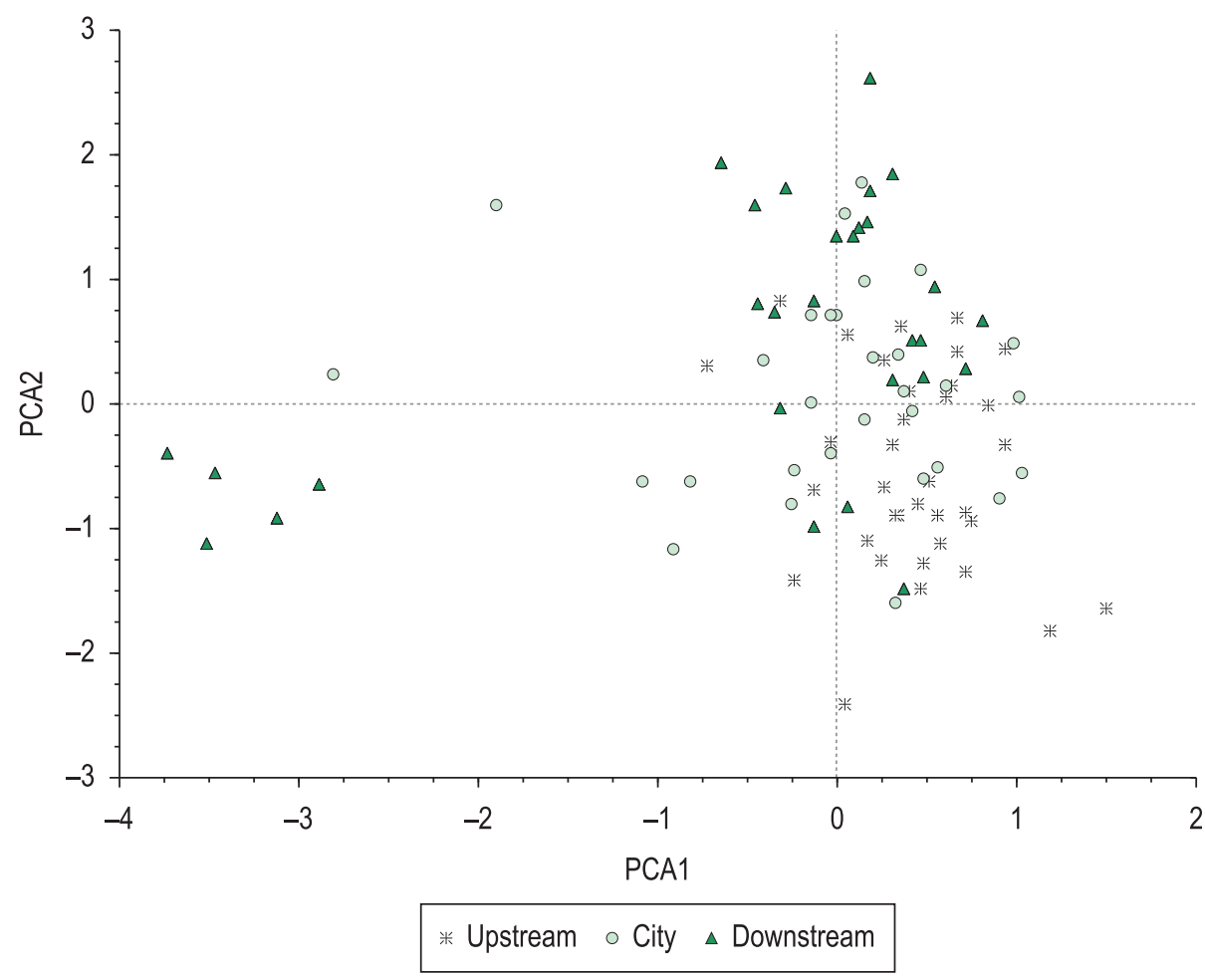

Figure 3. Ordination diagram by Principal Component Analysis (PCA) of scores and weights categorised the sites as upstream, city and downstream to urban rivers. 
physical characteristics (e.g., river slope, waterfalls) explain the oxygenation of water.

The conductivity values we recorded are relevant in the case of rivers passing through urban areas (e.g., the Xaxim, the Taquaruçu and the Lajeado São José Rivers) and/or rivers which are not characterised by marginal vegetation. Electrical conductivity values are more influenced by physical (climate, hydrology) and chemical factors (local geology, mineral solubility) and by human impacts (e.g., the use of fertilisers, changes in vegetation) than they are by biological factors (Pedrosa and Rezende, 1999). Besides the impact of organic matter and nutrients from urban areas, organic residues and chemical fertilisers from agricultural activities can change the chemical attributes of soil, which may contribute to an increased electrical conductivity. These electrical conductivity values may be up to four times higher in soils from areas cultivated with annual crops than in soils with native vegetation (Corrêa et al. 2009).

In the studied area, forests have been fragmented in recent years due to the clearing of land for crop farming. Farmland expansion intensely fragmented forests in southern Brazil (Martins, 2001). This gradual degradation of forests has an impact on water resources throughout the leaching of contaminated soils and waste from urban areas (domestic sewage, wastewater, garbage). This is accelerated by the lack of riparian forests, which can filter contaminants (Lima and Zakia 2004). Rivers with riparian vegetation have a better limnological quality (Lima and Zakia 2004).

In addition to serving a protective function, riparian forests lower water temperatures by providing shade. Lower water temperatures were recorded in the Irani River where a greater amount of forest provided shade, particularly closer to the headwaters. Silva and Sacomani (2000) recorded the influence of riparian forest on water temperature in the Pardo River and showed that it was always lower at locations that were protected by dense forest. Arcova and Ciccio (1999) also reported that differences in water temperature are more noticeable in micro-basins that are characterised by forest than in areas characterised by farming.

In this study, we found oxygenated aquatic environments, especially in the Irani River. In stretches of the river where physical energy was more intense, we observed higher DO concentrations. In addition, DO concentrations were higher in stretches of the river that had preserved banks. Souza and Tundisi (2000) found that the aquatic parameters were influenced to a lesser degree where stretches of the main stream of the JacaréGuaçu River were protected by a high degree of riparian forest than where there was no vegetation. We want to draw attention to the fact that the highest concentrations of swine farming in Brazil are found in the micro-basin region along the Irani River; it is likely that the presence of riparian vegetation contributes to the protection of the river's limnological characteristics.

COD, nitrogen and phosphorus are important parameters for analysing water pollution. In this study, we observed that these variables may have been influenced by soil use and human activity. Higher COD values were recorded in the São Domingos and Lajeado São José Rivers than in the other rivers we examined. This may be related to higher levels of organic matter being inputted into these rivers; both rivers are linked to urban areas. Silva and Sacomani (2000) found high COD values in sites with sewage sources. Chapman and Kimstach (1996) reported that superficial water may reach COD values of $20 \mathrm{mg} . \mathrm{L}^{-1}$; when COD values reach $200 \mathrm{mg} . \mathrm{L}^{-1}$ they are considered to be receptors of pollution sources. These results support other studies that demonstrate that urbanization interferes with water quality (Karn and Harada, 2001, Ouyang et al, 2006, Salomoni et al., 2007, Machado et al., 2009).

Regarding nitrogen compounds, ammonia was only found in high concentration in the Lajeado São José River (site RLSJ4) and originated from both diffused (farming areas that use fertilisers) and concentrated sources (domestic and industrial sewage dumps). The dominant inorganic nitrogen form in the rivers we examined was nitrate, as also observed by Domingos (2002) and Bubel (1998). The main nitrate sources in the water are nitrogen fertilisers (used in crops), which enter aquatic ecosystems through leaching (Baird, 2002) and tend to be concentrated because they are resistant to microbial degradation (Brigante et al., 2003). Arauzo et al. (2008) found that nitrogen concentrations in rivers were linked to the location's proximity to Madrid, Spain. Nitrite, an intermediate oxidation phase between ammonia and nitrate, is a consequence of recent pollution. Indeed, high nitrite concentrations have been observed in the Lajeado São José River, this latter being subjected to urban development and consequently to effluents from treatment stations.

The high phosphorus concentrations we observed in the Lajeado São José River, were related to urban effluents. Sampling sites located 
downstream of urban areas had higher phosphorus concentrations than sampling sites located upstream, suggesting that urban discharge are the greatest source of phosphorus, as also reported by Salamoni et al. (2007), Calijuri et al. (2008), Carneiro et al. (2009) and Cunha et al. (2010). This also provides support for the conclusion that there is a connection between high phosphorus concentrations and reductions in environmental quality (Simóes 2003, Donadio et al. 2005, Cunico et al. 2006, and Machado et al. 2009).

The PCA results allowed us to extract relevant information. The groupings, that comprise both physical and chemical variables, show different ways of using the soils and separate urban and rural rivers. The parameters responsible for that division are, mainly, electrical conductivity, total alkalinity and concentrations of total phosphorus, nitrite, nitrate and ammonia.

Samples from the Taquaruçu (RTQ2), Xaxim (RXX2) and Lajeado São José (RLJ4) Rivers were influenced by anthropogenic factors more than the other sites we examined. These sites had greater urban occupation and deeper riparian forest degradation than in all other sites we sampled. Our results are similar to those results found in studies from other regions (Mota, 1995; Sabater et al., 1996; Agatz et al., 1999; Sonnemann et al., 2001; Brito et al., 2005; Salomoni et al., 2007; Marotta et al., 2008; Machado et al., 2009, Cunha et al., 2010).

\section{Acknowledgements}

We thank Janet Higuti and Alex Fragoso for suggestions in the manuscript and Caroline Thaís Ravanello, Ericksen A. Raimundi and Margarete Tironi for their help in the field and in the lab. We acknowledge Fape/Unochapecó (Fundação de Apoio à Pesquisa) and Research Project Rede Guarani Serra Geral (CTHidro/ANA/ CNPq/ FAPESC) for their financial support.

\section{References}

Agatz, M., Asmus, RM. and Deventer, B. 1999. Structural changes in the benthic diatom community along eutrophication gradient on a tidal flat. Helgoland Marine Research, vol. 53, p. 92-101. http://dx.doi. org/10.1007/PL00012144

American Public Health Association - APHA. 1998. Standard Methods for Examination of water and wastewater. 20th ed. Washignton: APHA. 1161 p.

ARAÚJO, NB. and TEJERINA-GARRO, FL. 2007. Composição e diversidade da ictiofauna em riachos do Cerrado, bacia do ribeirão Ouvidor, alto rio Paraná, Goiás, Brasil. Revista Brasileira de Zoologia, vol. 24, no. 4, p. 981-990.

ARAUZO, M., MARTINEZ-BASTIDA, JJ., and VALLADOLID, M. 2008. Contaminacion por nitrogeno em el sistema "río-acuífero aluvial" de la cuenca del Jarama (Comunidad de Madrid, Espana) ¿Origen agrícola o urbano? Limnetica, vol. 27, no. 2, p. 195-210.

ARCOVA, FCS. and CICCO, V. 1999. Qualidade da água de microbacias com diferentes usos de solo na região de Cunha, estado de São Paulo. Scientia Forestalis, no. 56, p. 125-134.

BAIRD, C. 2002. Quimica ambiental. 2th ed. Porto Alegre: Bookman. 622 p.

BELLANI, EM. 2006. Balsas e balseiros no Rio Uruguai: (1930-1950). Cadernos do CEOM, vol. 19, no. 23, p. 73-97.

Bonai, NC., Souza-Franco, GM., Fogolari, O, Mocelin, DJC. and Dal Magro, J. 2009. Distribution of metals in the sediment of the Itá Reservoir, Brazil. Acta Limnologica Brasiliensia, vol. 21, no. 2, p. 245-250.

Bottin, J., Dal Magro, J., Souza-Franco, GM. and Mocelin, DJC. 2007. Avaliação limnológica da microbacia do lajeado passo dos índios, Chapecó, SC. O Biológico, vol. 69, no. 1, p. 31-39.

BRITO, LTL., Srinivasan, VS., SILVA, AdS., GHEYI, HR., Galvão, CO. and Hermes, LC. 2005. Influência das atividades antrópicas na qualidade das águas da bacia hidrográfica do Rio Salitre. Revista Brasileira de Engenharia Agrícola e Ambiental, vol. 9, no. 4, p. 596-602.

BRIGANTE, J., ESPÍNDOLA, ELG., POVINELLI, J. and NOGUEIRA, AM. 2003. Caracterização física, química e biológica da água do rio Mogi-Guaçu. In BRIGANTE, J. and ESPINDOLA, ELG., eds. Limnologia fluvial: um estudo no rio Mogi-Guaçu. São Carlos: RimaEditora. p. 55-76.

Brasil. Ministério das Cidades. Sistema Nacional de Informações sobre Saneamento - SNSA. 2010. Diagnóstico dos serviços de água e esgotos - 2008. Brasília: SNSA.

BUBEL, APM. 1998. Caracterizaçâo do Rio do Peixe (microregiáo geográfica de Botucatu - SP), em duas épocas do ano (período de seca e chuva). São Paulo: Universidade de São Paulo. [Dissertação de Mestrado em Engenharia Hidráulica e Saneamento].

CALIJURI, MC., CUNHA, DGF., QUEIROZ, LA., MOCCELLIN, J. and MIWA, ACP. 2008. Nutrients and chlorophyll-a concentrations in tropical rivers of Ribeira do Iguape Basin, SP, Brazil. Acta Limnologica Brasiliensia, vol. 20, no. 2, p. 131-138.

Carneiro, FM., Angelini, R., Carvalho, AR. and Bini, LM. 2009. Synchrony among limnological variables in a lotic system (Meia Ponte River, Goiás, Brazil). 
Acta Limnologica Brasiliensia, vol. 22, no. 1, p. 35-45.

Chapman, D. and Kimstach, V. 1996. Selection of water quality variables. In CHAPMAN, D. Water quality assessments: a guide to the use of biota, sediments and water in environmental monitoring. 2th ed. Cambridge: UNESCO, WHO, UNEP. p. 59-126.

CORREA, RM., FREIRE, MBGS., FERREIRA, RLC., FREIRE, FJ., PESSOA, LGM., MIRANDA, MA. and MELO, DVM. 2009. Atributos químicos de solos sob diferentes usos em perímetro irrigado no semiárido de Pernambuco. Revista Brasileira de Ciência do Solo, vol. 33, no. 2, p. 305-314.

Cunha, DGF., Bottino, F. and Calijuri, MC. 2010. Land use influence on eutrophication-related water variables: case study of tropical rivers with diferent degrees of anthropogenic interference. Acta Limnologica Brasiliensia, vol. 22, no. 1, p. 35-45. http://dx.doi.org/10.4322/actalb.02201005

CUNICO, AM., AGOSTINHO, AA. and LATINI, JD. 2006. Influência da urbanização sobre as assembléias de peixes em três córregos de Maringá, Paraná. Revista Brasileira de Zoologia, vol. 23, no. 4, p. 1101-1110.

Dal Pissol, A. and Souza-Franco, GM. 2003. Avaliação da qualidade das águas através de macroinvertebrados bentônicos em corpos de água no município de Maravilha (SC). Acta Ambiental Catarinense, vol. 2, no. 2, p. 7-21.

DENARDIN, VF. and SULZBACH, MT. 2005. Os possíveis caminhos da sustentabilidade para agropecuária da região oeste de Santa Catarina. Desenvolvimento em Questão, vol. 3, no. 6, p. 87-115.

DOBLINSKI, AF. SAMPAIO, SC., SILVA, VR., NÓBREGA, LHP., GOMES, SD. and DAL BOSCO, TC. 2010. Nonpoint source pollution by swine farming wastewater in bean crop. Revista Brasileira de Engenharia Agrícola e Ambiental, vol. 14, no. 1, p. 87-93.

DOMINGOS, MD. 2002. Limnologia do rio Betari (Iporanga-SP) e a relação com o estudo de conservação de sua bacia hidrográfica - subsidios para o desenvolvimento sustentável. São Paulo: Universidade de São Paulo. [Tese de Doutorado em Engenharia Hidráulica e Saneamento].

DONADIO, NMM., GALBIATTI, JA. and PAULA, RC. 2005. Qualidade da água de nascentes com diferentes usos do solo na bacia hidrográfica do córrego rico, São Paulo, Brasil. Engenharia Agrícola, vol. 25 , no. 1 , p. 115-125.

GOONETILLEKE, A., THOMAS, E., GINN, SG. and GILBERT, DC. 2005. Understanding the Role of Land Use in Urban Stormwater Quality Management. Journal of Environmental Management, vol. 74, p. 31-42. PMid:15572079. http://dx.doi. org/10.1016/j.jenvman.2004.08.006
Instituto Brasileiro de Geografia e Estatística - IBGE. 2002. Pesquisa nacional de saneamento básico, 2000. Rio de Janeiro: IBGE. (CD-ROM).

Instituto Brasileiro de Geografia e Estatística - IBGE.2008. Produção Pecuária municipal 2007. Rio de Janeiro: IBGE. vol. 35, p. 1-62.

HANNAFORD, MJ., MT. BARBOUR, and RESH, VH. 1997. Training reduces observer variability in visual-based assessments of stream habitat. Journal of the North American Benthological Society, vol. 16, no. 4, p. 853-860. http://dx.doi.org/10.2307/1468176

KARN, SK and HARADA, H. 2001. Surface water pollution in three urban territories of Nepal, India, and Bangladesh. Environmental Management, vol. 28, no. 4, p. 483-496. PMid:11494067.

http://dx.doi.org/10.1007/s002670010238

LIMA, WP. and ZAKIA, MJB. 2004. Hidrologia de matas ciliares. In RODRIGUES, RR. and LEITÃOFILHO, HF., eds. Matas ciliares: conservação e recuperação. São Paulo: EdUSP, FAPESP. p. 33-44.

MACHADO, WCP., BECEGATO, VA. and BITTENCOURT, AVL. 2009. Anthropic influence in the water quality of the river basin that supplies the Pato Branco Municipality-PR. Brazilian Archives of Biology and Technology, vol. 52, no. 1, p. 221-232. http://dx.doi.org/10.1590/S151689132009000100027

MAESTRI, M. 2005. Os senhores da Serra: a colonização italiana do Rio Grande do Sul. 2th ed. rev. e ampl. Passo Fundo: EdiUPF.

MAROTTA, H., SANTOS, RO. and ENRICHPRAST, A. 2008. Monitoramento limnológico: um instrumento para a conservação dos recursos hídricos no planejamento e na gestão urbano-ambientais. Ambiente \& Sociedade, vol. 11, no. 1, p. 67-79. PMid:18449218. http://dx.doi.org/10.1590/S1414753X2008000100006

MARTINS, SJ. 2001. Recuperação de matas ciliares. Viçosa: Editora Conceito. 90 p.

MATTIAS, JL., CERETTA, CA., NESI, CN., GIROTTO, E, TRENTIN, EE., LOURENZI, CR. and VIEIRA, RCB. 2010. Copper, zinc and manganese in soils of two Watersheds in Santa Catarina with Intensive use of pig slurry. Revista Brasileira de Ciência do Solo, vol. 34, no. 4, p.1445-1454. http://dx.doi.org/10.1590/S010006832010000400040

MEIRELLES-PEREIRA, F., MAROTTA, H. and ESTEVES, FA. 2005. Eutrofização artificial em corpos límnicos e a economia capitalista moderna: uma analise capitalista. In ROLAND, F., CESAR, D. and MARINHO, M., eds. Lições de Limnologia. São Carlos: Rima Editora. p. 75-92.

MCKIE, BG., SCHINDLER, M, GESSNER, M. O. and MALMQVIST, B. 2009. Placing biodiversity and ecosystem functioning in context: environmental 
perturbations and the effects of species richness in a stream field experiment. Oecologia, vol. 160, no. 4, p. 757-770. PMid:19390869. http://dx.doi. org/10.1007/s00442-09-1336-7

MIRANDE, V., ROMERO, N., BARRIONUEVO, MA., MEONI, GSB., NAVARRO, MG., APELLA, MC. and TRACANNA, BC. 1999. Human impact on some limnological characteristics of the Gastona River (Tucumán, Argentina). Acta Limnologica Brasiliensia, vol. 11, no. 2, p. 101-110.

MOTA, S. 1995. Preservação e conservação e recursos hidricos. 2th ed. Rio de Janeiro: ABES. 200 p.

OUYANG, T., ZHU, Z. and KUANG, Y. 2006. Assessing Impact of Urbanization on River Water Quality In The Pearl River Delta Economic Zone, China. Environmental Monitoring and Assessment, vol. 120, no. 1-3, p. 313-325. PMid:16738781. http:// dx.doi.org/10.1007/s10661-005-9064-x

PEDROSA, P. and REZENDE, CE. 1999. As muitas faces de uma lagoa. Ciência Hoje, vol. 6, no. 153, p. $40-47$.

PRAUS, P. 2007. Urban water quality evaluation using multivariate analysis. Acta Montanistica SlovacA, vol. 12 , p. $150-158$.

RAHMAN, A. and LEE, HC. 1997. Domestic Water Contamination in Rapdly Growing Megacities of Asia: Case of Karachi, Pakistan. Environmental Monitoring and Assessment, vol. 44, p.339-360. http://dx.doi.org/10.1023/A:1005747732104

RENK, A. 2006. A luta da erva: um ofício étnico no oeste catarinense. 2th ed. rev. Chapecó: Grifos. 250 p.

Sabater, S., Guasch, H., Picón, A., Romaní, A. and Muñoz, I. 1996. Using diatoms communities to monitor water quality in a river after the implementation of a sanitation plan (River Ter, Spain). In WHITTON, BA. and ROTT, E., eds. Use of Algae for Monitoring Rivers II. Insbruck: Institut für Botanik, Universität Innsbruck. p. 97-103.

SALOMONI, SE., ROCHA, O. and LEITE, EH. 2007. Limnological characterization of Gravataí River, Rio Grande do Sul. Acta Limnologica Brasiliensia, vol. 19, no. 1, p. 1-14.

Schulz, UH. and Martins-Junior, H. 2001. Astyanax fasciatus as bioindicator of water pollution of Rio dos Sinos, RS. Brazil. Brazilian Journal of Biology, vol. 61, no. 4, p. 615-22. http://dx.doi.org/10.1590/ S1519-69842001000400010
Schuster, KF. and Souza-Franco, GM. 2003. Macroinvertebrados bentônicos como bioindicadores da qualidade das águas da microbacia do Lajeado São José, Chapecó, Santa Catarina. Acta Ambiental Catarinense, vol. 2, no. 1, p. 7-21.

SILVA, AMM. and SACOMANI, LB. 2000. Using chemical and physical parameters to define the quality of Pardo River water (Botucatu - SP - Brazil). Water Reseach, vol. 35, no. 6, p. 1609-1616.

SIMÔES, LB. 2003. A importância das matas Riparias no controle da poluição difusa. In HENRY, R. Ecótonos nas interfaces dos ecossistemas aquáticos. São Carlos: RimaEditora. p. 47-60.

Sonneman, JA., Walsh, CJ., Breen, PF. and Sharpe, AK. 2001. Effects of urbanization on streams of the Melbourne region, Victoria, Australia. II. Benthic diatom communities. Freshwater Biology, vol. 46, no. 4 , p. $553-565$

SOUZA, ADG. and TUNDISI, JG. 2000. Hidrogeochemical comparative study of the Jaú and Jacaré-Guaçu River watersheds, São Paulo, Brazil. Revista Brasileira de Biologia $=$ Brazilian Journal of Biology, vol. 60, no. 4, p. 563-570.

STATSOFT Inc. 2001. STATISTICA (data analysis software system). version 6.1. Available from: <www. statsoft.com>.

STONE, KC., HUNT, PG., HUMENIK, FJ. and JOHNSON, MH. 1998. Impact of swine waste application on ground and stream water quality an eastern coastal plain watershed. American Society of Agricultural Engineers, vol. 41, no. 6, p. 1665-1670.

WENTZ, LIM. 2004. Os caminhos da madeira: regiāo norte do Rio Grande do Sul (1902- 1950). Passo Fundo: EdiUPF. 187 p.

WERLANG, AA. 2006. Disputas e ocupação do espaço no oeste catarinense: a atuação da companhia territorial Sul Brasil. Chapecó: Argos. 149 p.

ZHANG, H. 2007. The orientation of water quality variation from the metropolis river-Huangpu River, Shanghai. Environmental Monitoring and Assessment, vol. 127, no. 1-3, p. 429-434. PMid:16957852. http://dx.doi.org/10.1007/s10661-006-9292-8

ZIMMERMANN; CM.; GUIMARÃES; OM. and ZAMORA, PGP. 2008. Avaliação da qualidade do corpo hídrico do rio Tibagi na regiáo de Ponta Grossa utilizando análise de componentes principais (PCA). Ponta Grossa, PR, Brasil. Química Nova, vol. 31, no. 7. 